\title{
Antillean manatee Trichechus manatus manatus (Sirenia: Trichechidae) as a motile ecosystem of epibiont fauna in the Caribbean Sea, Mexico
}

\author{
Marco Violante-Huerta ${ }^{*}$, Raúl Díaz-Gamboa and Uriel Ordónez-López ${ }^{2}$ \\ 1 Universidad Autónoma de Yucatán, Campus de Ciencias Biológicas y Agropecuarias, Carretera Mérida-Xmatkuil Km. 15.5, CP. \\ 97100, Mérida. Yucatán, México. Email: marco violante@hotmail.com (MVH), raul.diaz@correo.uady.mx (RDG). \\ 2 Instituto Politécnico Nacional, Centro de Investigación y Estudios Avanzados-Unidad Mérida. Km 6, carretera a Progreso, CP. \\ 97310, Mérida. Yucatán, México. Email: uriel.ordonez@cinvestav.mx (UOL) \\ *Corresponding author: marco violante@hotmail.com
}

\begin{abstract}
The study of epibionts allows inferring ecological, biogeographic and health aspects of the host species (basibiont), and their study on marine mammals is scarce. The aim of this work was to characterize the epibiont fauna associated with the skin of captive individuals of the West Indian manatee in three sites from the Mexican Caribbean. In autumn 2014, 22 dorsal skin scrapings were collected from 11 captive manatees. The biological material was scraped off the skin with a blunt spatula, covering $100 \mathrm{~cm}^{2}$ of sampled area of the dorsal skin of each manatee. Samples were immediately fixed in $8 \%$ formalin solution and placed in labeled vials for laboratory analysis. We used specialized literature to identify epibionts at the lowest taxonomic level possible. A total of 1,353 individuals from 31 taxa were found, belonging to eight phyla. Twenty nine taxa are new records of epibionts from Sirenians. The nematodes Monhystera sp. and Rabdolaimus sp., the adult and larvae of copepods from the Order Harpacticoida, the foraminifer Ammonia sp. and the rotifer Lecane sp. were the dominant epibionts. These new interactions may suggest that in the Caribbean Sea, the manatee skin represents a nutrient-rich substrate for an opportunistic fauna that is more diverse than previously estimated.
\end{abstract}

Los epibiontes pueden ser estudiados para inferir aspectos ecológicos, biogeográficos y de la salud de la especie que los alberga (basibionte). Su estudio es muy escaso en mamíferos marinos por lo que el objetivo de este trabajo fue caracterizar la fauna epibionte asociada a la piel de individuos cautivos del manatí Antillano en tres localidades del Caribe mexicano. En otoño de 2014 se colectaron 22 muestras de piel de 11 manatíes cautivos. El material biológico se obtuvo por medio de un raspado superficial con una espátula blanda cubriendo un área de $100 \mathrm{~cm}^{2}$ de la piel del dorso del manatí. Las muestras se fijaron inmediatamente en una solución de formalina al $8 \%$ y fueron colocadas en frascos etiquetados para su análisis en laboratorio. Con el uso de literatura especializada, se realizó la identificación del material al menor nivel taxonómico posible. Se encontraron un total de 1,353 individuos de 31 taxa pertenecientes a ocho fila. De ellos, 29 son nuevos registros de epibiontes para el Orden Sirenia. Los nematodos Monhystera sp. y Rhabdolaimus sp., las larvas nauplio y adultos de copépodos del Orden Harpacticoida, foraminíferos Ammonia sp. y los rotíferos Lecane sp. fueron dominantes. Estas nuevas interacciones sugieren que, en el Mar Caribe, la piel de los manatíes representa un sustrato rico en nutrientes para una fauna oportunista que es más diversa de lo previamente estimado.

Keywords: diatom, invertebrates, manatee, marine mammals, Mexican Caribbean, opportunistic fauna, symbiosis.

@ 2017 Asociación Mexicana de Mastozoología, www.mastozoologiamexicana.org

\section{INTRODUCTION}

The manatee Trichechus manatus Linnaeus, 1758 is a marine mammal endangered of extinction, characterized by a broad distribution area, that inhabits marine, estuarine, and freshwater systems in tropical America, mainly in the Caribbean Sea (Deutsch et al. 2008). In Florida, the manatee subspecies T. m. latirostris Harlan, 1824 has been recognized as a basibiont organism that functions as a wandering ecosystem for various epibiont groups of algae and aquatic invertebrates (Bledsoe et al. 2006; Franckovich et al. 2015), while the Caribbean subspecies T. m. manatus Linnaeus, 1758 has been little studied in this regard (Morales-Vela et al. 2008; Suárez-Morales et al. 2010; Violante-Huerta and SuárezMorales 2016). Studying epibiont communities in large vertebrates is an indirect method to obtain information on the biogeography, ecology and health of the respective basibiont (Fernández et al. 1998; Liria-Loza 2011). The objective of this investigation is to report new evidence on the diversity of epibiont organisms growing on the skin of the manatee in the Mexican Caribbean.

\section{MATERIALS AND METHODS}

In the autumn of 2014, a total of 22 samples were collected from the skin of the back of eleven captive manatees, and salinity (salt) was recorded, in three localities of the Mexican Caribbean Sea: four manatees (two adult females, one adult male and one calf) kept in the marine aquarium (27 ppm salt) Dolphin Discovery Puerto Aventuras ( $20^{\circ} 30^{\prime} 02.13^{\prime \prime} \mathrm{N}$, $-87^{\circ} 13^{\prime} 32.25^{\prime \prime} \mathrm{W}$ ), six (three adult females, one adult male and two calves) living in an estuary (18 ppm salt) at Xcaret eco-archaeological park ( $\left.20^{\circ} 34^{\prime} 42.50^{\prime \prime} \mathrm{N},-87^{\circ} 07^{\prime} 12.91^{\prime \prime} \mathrm{W}\right)$ and one adult male living in the freshwater system (7 ppm salt) at Centro de Atención y Rehabilitación de Mamíferos Acuáticos (Center for Care and Rehabilitation of Aquatic Mammals; CARMA, for its acronym in Spanish), Chetumal Bay $\left(18^{\circ} 41^{\prime} 22.19^{\prime \prime} \mathrm{N},-88^{\circ} 15^{\prime} 47.09^{\prime \prime} \mathrm{W}\right)$. The biological mate- 
rial was collected by scrapping off an area of healthy skin on the back of each manatee with a blunt plastic spatula (Suárez-Morales et al. 2010; Figure 1) covering $100 \mathrm{~cm}^{2}$ (10 $x 10 \mathrm{~cm}$ quadrants). Immediately afterwards, samples were fixed and preserved in a $8 \%$ formalin solution and placed in labeled vials for analysis in the laboratory. The material was identified to the lowest taxonomic level possible assisted with specialized literature.

The complexity of the epibiont community on the skin of manatees, the lack of information on the physical variables of the substrate (skin), the physicochemical variability of water between localities, and the lack of homogeneity in age and sex of the 11 manatees sampled, were all factors that restrained the conduct of robust statistical studies with the data obtained to establish unequivocal relationships. Consequently, only percent total abundance figures were used.

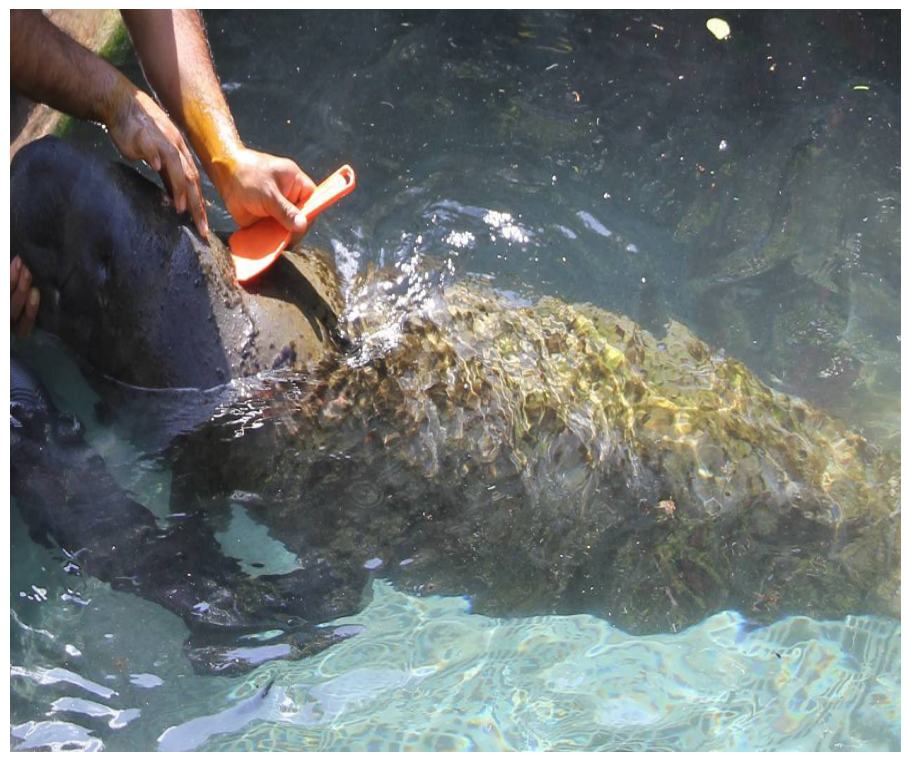

Figure 1. Surface scrape technique used for sampling epibionts found on the West Indian manatee in Mexico. Photograph by Raúl Díaz-Gamboa.

\section{RESULTS AND DISCUSSION}

A total of 1,353 specimens of 31 taxa were found, belonging to eight phyla (Table 1). The dominant taxa were nematodes (39\%), harpacticoid copepods in naupliar and adult stages ( $27.3 \%)$, foraminifera of the genus Ammonia (7.6\%) and rotifers of the genus Lecane (8.9\%). Large amounts of microalgae directly interacting were also observed (i. e., pennate diatoms) that were neither identified nor quantified.

The interactions of epibiont crustaceans such as harpacticoid and tanaid copepods have been examined in free-living manatees and are recognized as harmless to the health of the specimens studied despite its prevalence and high abundance. The presence of these crustaceans has not been associated with injured skin that could suggest a parasitic interaction (Morales-Vela et al. 2008; Suárez-Morales et al. 2010). At present, there are three species of harpacticoid copepods (Huys 2016; Violante-Huerta and SuárezMorales 2016) and two species of tanaid copepods (Bonde
2005; Morales-Vela et al. 2008; Ortiz et al. 2010) that have been reported as well-established manatee epibionts. In addition to the presence of unidentified harpacticoid copepods and the previously recorded tanaid Sinelobus stanfordi, the present study includes five groups of crustaceans that had not been previously found as manatee epibionts: Cryprididae, Loxoconchidae, Acartia lilljeborgii, Colomastix and Alpheidae. These groups were unrelated to skin injuries in the manatee individuals sampled.

The species Acartia lilljeborgii is considered a strictly planktonic species (Campos and Suárez-Morales 1994); hence, its presence on manatee skin could be an incidental finding. In addition, groups of microinvertebrates were found on healthy skin that had not been previously observed as epibionts of manatees in the Caribbean: fora-

Table 1. Composition of the epibiont community associated with the skin of the West Indian manatee in the Mexican Caribbean. Association record (AR) ${ }^{2}$. Total abundance\% (TA\%).

\begin{tabular}{|c|c|c|c|c|c|c|}
\hline \multirow{2}{*}{ Phylum } & \multirow{2}{*}{ Taxon } & \multicolumn{3}{|c|}{ Sampled locality ${ }^{1}$} & \multirow{2}{*}{$(\mathrm{AR})^{2}$} & \multirow{2}{*}{$(\mathrm{TA} \%)$} \\
\hline & & DD & $X C A$ & $\mathrm{CHE}$ & & \\
\hline \multirow[t]{7}{*}{ FORAMINIFERA } & Ammonia & $\mathrm{x}$ & $\mathrm{x}$ & $x$ & & 7.6 \\
\hline & Bolivina & & $\mathrm{x}$ & & & 0.2 \\
\hline & Epistominidae & & $\mathrm{x}$ & & & 1.3 \\
\hline & Haplophragmoides & & $x$ & & & 1.0 \\
\hline & Massilina & & $x$ & & & 0.8 \\
\hline & Textularia & & $\mathrm{x}$ & & & 0.4 \\
\hline & Trochamina & & $x$ & & & 1.3 \\
\hline RADIOZOA & Spongodiscidae & & $x$ & & & 0.1 \\
\hline \multirow[t]{2}{*}{ ROTIFERA } & Bdelloidea & & $\mathrm{x}$ & $x$ & & 0.9 \\
\hline & Lecane & & $\mathrm{x}$ & $x$ & & 8.9 \\
\hline \multirow[t]{10}{*}{ NEMATODA } & Archepsilonema & & $\mathrm{x}$ & & & 0.2 \\
\hline & Butlerius & & & $x$ & & 0.1 \\
\hline & Miconchus & & $\mathrm{x}$ & & & 0.4 \\
\hline & Mononchoides & & $\mathrm{x}$ & $x$ & & 1.7 \\
\hline & Monochromadora & $x$ & $\mathrm{x}$ & & & 0.5 \\
\hline & Monhystera & $x$ & $x$ & $x$ & & 16.4 \\
\hline & Teratocephalus & & $x$ & $x$ & & 2.4 \\
\hline & Tylenchus & & $x$ & & & 0.6 \\
\hline & Rabditidae & & $\mathrm{x}$ & $\mathrm{x}$ & & 1.6 \\
\hline & Rabdolaimus & $x$ & $x$ & & & 15.1 \\
\hline \multirow[t]{2}{*}{ ANNELIDA } & lospilidae & $x$ & $x$ & & & 0.1 \\
\hline & Pilargiidae & & $\mathrm{x}$ & & & 0.2 \\
\hline PLATYHELMINTHES & Digenia & $x$ & $\mathrm{x}$ & & & 0.1 \\
\hline MOLLUSCA & Limacina & & $x$ & & & 0.4 \\
\hline \multirow[t]{7}{*}{ ARTHROPODA } & Cyprididae & $x$ & $x$ & $x$ & & 7.4 \\
\hline & Loxoconchidae & & $x$ & & & 0.2 \\
\hline & Acartia lilljeborgii & & & $x$ & & 0.7 \\
\hline & $\begin{array}{l}\text { Harpacticoida } \\
\text { (adult, copepodite } \\
\text { and naupli) }\end{array}$ & $x$ & $x$ & $x$ & $r$ & 27.3 \\
\hline & Colomastix & $x$ & $x$ & & & 1.1 \\
\hline & Sinelobus stanfordi & & $\mathrm{x}$ & & $r$ & 0.6 \\
\hline & Alpheidae & & & $x$ & & 0.1 \\
\hline
\end{tabular}

${ }^{1} \mathrm{DD}=$ Dolphin Discovery Puerto Aventuras, $\mathrm{XCA}=\mathrm{Xcaret}, \mathrm{CHE}=(\mathrm{CARMA})$ Chetumal bay, $\mathrm{X}=$ Presence, ${ }^{2} \mathrm{r}=$ epibiont interaction previously reported. 
miniferans $(n=7)$, radiolarians $(n=1)$, rotifers $(n=2)$, nematodes ( $n=10$, dominant), annelids $(n=2)$, mollusks ( $n=$ $1)$, and platyhelminthes $(n=1)$. The findings in this study deepen our knowledge about the external interactions in sirenians, since 29 of the 31 taxa observed in this work are new records of epibionts for the subspecies T. m. manatus and for the order Sirenia around the world.

The difference between the diversity of taxa observed in this research and previous reports may have been associated with the captivity status of the specimens sampled. This is due to the hydrologically more stable environments, which facilitate the establishment of colonizing organisms on the available substrate (Railkin 2004). In addition, captivity reduces the exposure of individuals to fluctuations in water salinity and temperature - the primary variables that influence the known load of epibionts in free-living manatees (Bledsoe et al. 2006). In addition, captivity favors the retention of nutrients, suspended detritus, bacteria and microflora, which ultimately become part of the biofilm that develops on the skin of manatees. These are likely utilized as food sources for the opportunistic microfauna reported, a common behavior for epibiont organisms (Humes 1964; Bledsoe et al. 2006).

Given the complexity associated with the study of epibiont communities and the richness of species associated with the skin of captive and free-living manatees, it is essential to record hydrological variables, assess the influence of the immune status of the manatee (Halvorsen and Keith 2008), correlate the physical composition of the skin (Wahl and Mark 1999; Wahl and Hopper 2002), and analyze the parasitizing potential of opportunistic species, to better understand the ecological niche of manatees as a wandering substrate in the western Caribbean.

\section{ACKNOWLEDGMENTS}

To Centro de Atención y Rehabilitación de Mamíferos Acuáticos (CARMA), Chetumal Bay, especially to Heladio Pérez and the Secretariat of Ecology and Environment of Quintana Roo; to the technical support group of the Xcaret Park and Dolphin Discovery "Puerto Aventuras"; to Juan Lara-Rodríguez for technical support in the field; to the Laboratory of Marine Plankton Ecology at CINVESTAV U-Mérida, for providing its facilities for sample analysis; and to the anonymous reviewers who contributed to improve this work. M. E. Sánchez-Salazar translated the manuscript into English.

\section{LITERATURE CITED}

Bledsoe, E., K. Harr, M. Cichra, R. Bonde, and M. Lowe. 2006. A comparison of biofouling communities associated with freeranging and captive Florida manatees (Trichechus manatus latirostris). Marine Mammal Science 22:997-1003.

Bonde, R., P. Lewis, D. Samuelson, C. Self-Sullivan, N. Auil, and J. PoweLL. 2005. Belize Manatee (T. manatus manatus) EpibiontsSEM Viewing Techniques. Sirenews 43:17.

Campos, A., and E. SuÁrez-Molares. 1994. Copépodos pelágicos del Golfo de México y Mar Caribe, 1. Biología y Sistemática. Consejo Nacional de Ciencia y Tecnología/ Centro de Investigaciones de Quintana Roo. Chetumal, México.

Deutsch, C. J., C. Self-Sullivan, and A. Mignucci-Giannoni. 2008. Trichechus manatus. The IUCN Red List of Threatened Species 2008: e.T22103A9356917.

Fernández, L., J. Parapar, E. González-Gurriarán, And R. Muiño. 1998. Epibiosis and ornamental cover patterns of the spider crab Maja squinado on the Galicians coast, Northwestern Spain: Influence of behavioral and ecological characteristics of the host. Journal of Crustacean Biology 18:728-737.

Franckovich, T., M. Sullivan, And N. Stacy. 2015. Three new species ofTursiocola (Bacillariophyta) from the skin of the West Indian manatee (Trichechus manatus). Phytotaxa 204:33-48.

Halvorsen, K., AND E. Keith. 2008. Inmunosuppression cascade in the Florida manatee (Trichechus manatus latirostris). Aquatic Mammals 34:412-419.

Humes, A. 1964. Harpacticus pulex, a new species of copepod from the skin of a porpoise and a manatee in Florida. Bulletin of Marine Science of the Gulf and Caribbean 14:517-528.

Huys, R. 2016. Harpacticoid copepods-their symbiotic associations and biogenic substrata: a review. Zootaxa 4174:448-729.

LIRIA-LozA, A. 2011. Ecosistemas errantes: epibiontes como indicadores biogeográficos de tortugas marinas en Canarias. Tesis Doctoral. Universidad de Las Palmas de Gran Canaria. España.

Morales-Vela, B., E. Suárez-Morales, J. Padilla-Saldivar, and R. HerAd. 2008. The tanaid Hexapleomera robusta (Crustacea: peracarida) from the Caribbean manatee, with comments on other crustacean epibionts. Journal of the Marine Biological Association of the United Kingdom 88:591-596.

Ortiz, M., A. Álvarez-Alemán, and J. Angulo-Valdés. 2010. Dos nuevos registros de Crustáceos asociados a la piel del manatí Trichechus manatus (Chordata, Mamalia, Sirenia) de la región noroccidental de Cuba. Revista de Investigaciones Marinas 312:91-95.

RaILKIN, A. I. 2004. Marine Biofouling: Colonization Processes and Defenses. CRC Press. Washington, U. S. A.

Suárez-Morales, E., B. Morales-Vela, J. Padilla-Saldivar, And M. SilvaBRIANO. 2010. The copepod Balaenophilus manatorum (Ortíz, Lalana and Torres, 1992) (Harpacticoida), an epibiont of the Caribean manatee. Journal of Natural History 44:847-859.

Violante-Huerta, M., and E. SuÁrez-Morales. 2016. The epiphytic copepod Metis holothuriae (Edwards, 1841) (Harpacticoida) a new epibiont of the Caribbean manatee. Crustaceana 89:639-644.

WAHL, M., AND O. MARCK. 1999. The predominantly facultative nature of epibiosis: experimental and observational evidence. Marine Ecology Progress Series 187:59-66.

WAHL, M., AND K. HoPPE. 2002. Interactions between substratum rugosity, colonization density and periwinkle grazing efficiency. Marine Ecology Progress Series 225:239-249.

\section{Associated editor: Juan Pablo Gallo}

Submitted: June 30, 2017; Reviewed: August 17, 2017;

Accepted:September 13, 2017; Published on line:September 26, 2017. 
